\title{
LEAF OPTICAL PROPERTIES REFLECT CHANGES OF PHOTOSYNTHETIC INDICES IN APPLE TREES
}

\author{
Kristina Laužikè', Giedrè Samuolienè $\dot{1}^{1,2}$ \\ ${ }^{1}$ Lithuanian Research Centre for Agriculture and Forestry, Lithuania \\ ${ }^{2}$ Aleksandras Stulginskis University, Lithuania \\ K.Lauzike@1sdi.lt
}

\begin{abstract}
The impact of light penetration into crown and the effect of rootstocks and distance between trees on photosynthetic behaviour were analysed. Apple cultivar 'Auksis' was grafted onto dwarfing rootstock P60 and super-dwarfing rootstock P22 and planted at different distances $(3 \times 1 \mathrm{~m}, 3 \times 0.75 \mathrm{~m}$ and $3 \times 0.5 \mathrm{~m})$. Nitrogen balance index and photochemical reflectance index were measured at two heights: $0.8 \mathrm{~m}$ above ground inside the canopy and $1.5 \mathrm{~m}$ above ground outside the canopy; specific leaf area, fresh and dry weight were evaluated from all canopy. The significantly positive effect of dwarfing rootstock P60 on all tested indices was observed comparing to P22 rootstock. Increasing density between trees lead to a decreased specific leaf area and increased nitrogen balance index. The dry and fresh weight ratio and photochemical reflectance index were also significantly affected, but no general tendency was identified. Photochemical reflectance index was not affected by light penetration into canopy, but the nitrogen balance index significantly decreased in the upper part of the canopy. Summarizing, it can be stated that decreasing light penetration into the crown results in an increase in the specific leaf area and photochemical reflectance index, and leads to a decrease in dry and fresh weight ratio and nitrogen balance index.
\end{abstract}

Key words: apple tree, specific leaf area (SLA), nitrogen balance index (NBI), Photochemical Reflectance Index (PRI).

\section{Introduction}

The plant growth and photosynthetic productivity are strongly influenced by environmental factors. The light is the essential source of energy and an external signal for regulating processes in plants. Photosynthetic productivity depends on many factors, such as light, water, $\mathrm{CO}_{2}$, nutrients and other elements like leaf canopy size and architecture (Long et al., 2006). During photosynthetic processes, solar energy is bounding to dry matter, thus it is possible to estimate photosynthetic behaviour of the plant. An increase in leaf photosynthesis translates into an increase in biomass. The productivity of the biomass also depends on the optimal plant photosynthesis system work (Long et al., 2006; Hüner et al., 2016).

Specific leaf area (SLA), which is defined as the leaf area per unit of dry leaf mass, is an important component linking plant carbon and water cycles as well as quantifying plant physiological processes. SLA regulates plant physiological processes, such as light capture, growth rates and life strategies (Ali et al., 2017; Yao et al., 2016).

Non-destructive methods determining plant leaf area are useful instruments in physiological, ecological and agronomic research. Reflectance indices offer non-intrusive tools for rapidly inferring several functionally important leaf and canopy properties (Sala et al., 2015; Gamon \& Surfus, 1999). Photochemical reflectance index (PRI) is related with photosystem II (PSII) via the xanthophyll cycle and can be used as a proxy for light use efficiency. Thus, PRI was also applied as an active probe of pigment conversion (Gamon \& Surfus 1999). Weng et al. (2010) found that both PRI and PSII efficiency decreased in Mangifera indica leaves with the increase in illumination. Moreover, the PSII efficiency-PRI relationship varied with temperature and leaf colour. Chlorophyll index (Chl) and the nitrogen balance index (NBI) describes the relative chlorophyll and nitrogen content of the same leaves. Nitrogen index is capable of assessing $\mathrm{N}$ dynamics in apple tree systems (Cerovic et al., 2012; Overbeck et al., 2018). Moreover, such methods allow repeat sampling of changing optical properties during leaf development.

It was reported that optical properties and photosynthetic indices were affected by seasonal changes in mango, Phlomis fruticosa (Weng et al., 2010; Stagakis et al., 2014), depending on the water status in woody perennial plants (Hmimina et al., 2014) and light penetration into crown for Zea mays and Phlomis fruticosa (Cheng et al., 2013; Stagakis et al., 2014). However, there is no data about leaf optical property relationship with photosynthetic indices in apple trees. Thus, the aim of the study was to find out the impact of light penetration into crown and the effect of rootstocks and distance between trees on photosynthetic behaviour of apple trees.

\section{Materials and Methods \\ Plant material and growing conditions}

A field experiment was carried out in an intensive orchard at the Institute of Horticulture, Lithuanian Research Centre for Agriculture and Forestry, Lithuania. The apple (Malus domestica Borkh.) cultivar 'Auksis' was grafted on rootstocks P22 and P60. Trees were planted in 2001 in single rows spaced $1 \mathrm{~m}, 0.75 \mathrm{~m}$ and $0.5 \mathrm{~m}$ apart with $3 \mathrm{~m}$ between rows. Pest and disease management was carried out 
according to the integrated plant protection practices, and the orchard was not irrigated. Soil conditions of the experimental orchard were as follows: clay loam, $\mathrm{pH} 7.3$, humus 2.8\%, $\mathrm{P}_{2} \mathrm{O}_{5} 255 \mathrm{mg} \mathrm{kg}^{-1}, \mathrm{~K}_{2} \mathrm{O} 230$ $\mathrm{mg} \mathrm{kg}^{-1}$. Three single trees were fully randomized. Measuruments and leaf samples were taken in 2017 in the middle of July (beginning of apple maturity) and at the end of August (harvest time).

\section{Optical leaf indices}

Photochemical reflectance index (PRI)

PRI was evaluated using non-destructive method (CI-710 Leaf spectrometer, USA) from five leaves from each tree at two heights: $0.8 \mathrm{~m}$ above ground inside the canopy and $1.5 \mathrm{~m}$ above ground outside the canopy. The PRI combines reflectance at 531 $\mathrm{nm}$ (R531) with a reference wavelength insensitive to short-term changes in light energy conversion efficiency (R570) and normalizes it:

$\mathrm{PRI}=\left(\mathrm{R}_{531}-\mathrm{R}_{570}\right) /\left(\mathrm{R}_{531}-\mathrm{R}_{570}\right)$

Nitrogen balance index (NBI)
NBI was evaluated using non-destructive measurement of leaf chlorophyll and flavonoid content in the epidermis (Dualex ${ }^{\circledR} 4$, USA) from five leaves from each tree at two heights: $0.8 \mathrm{~m}$ above ground inside the canopy and $1.5 \mathrm{~m}$ above ground outside the canopy.

\section{Biometric measurements}

To determine the leaf area $\left(\mathrm{cm}^{2}\right)$, twenty leaves were randomly sampled from the whole tree canopy and measured with a leaf area meter (AT Delta - T Device, UK). The dry mass of twenty leaves was determined by drying apple leaves at $105^{\circ} \mathrm{C}$ (Venticell 222, Medcenter Einrichtungen, Gräfeling, Germany) to constant weight. SLA was defined as the leaf area per unit of dry leaf mass, usually expressed in $\mathrm{cm}^{2} \mathrm{~g}^{-1}$.

\section{Statistical analysis}

The data were processed using two-way and threeway analysis of variance (ANOVA) at the confidence levels $\mathrm{P} \leq 0.05$ and $\mathrm{P} \leq 0.01$.

Table 1

The effect of light penetration into the canopy, rootstock, the distance between trees and seasonality on the photochemical reflectance index (PRI) and nitrogen balance status (NBI) in 'Auksis' apple tree leaves

\begin{tabular}{|c|c|c|c|c|c|c|c|c|c|}
\hline \multirow{3}{*}{ Rootstock } & \multirow{3}{*}{ Distance } & \multicolumn{2}{|c|}{$\begin{array}{c}\text { Photochemical } \\
\text { Reflectance Index }\end{array}$} & \multicolumn{2}{|c|}{$\begin{array}{c}\text { Photochemical } \\
\text { Reflectance Index }\end{array}$} & \multicolumn{2}{|c|}{$\begin{array}{l}\text { Nitrogen Balance } \\
\text { Index } \\
\end{array}$} & \multicolumn{2}{|c|}{$\begin{array}{l}\text { Nitrogen Balance } \\
\text { Index }\end{array}$} \\
\hline & & $\begin{array}{l}0.8 \mathrm{~m} \\
\text { above } \\
\text { ground }\end{array}$ & $\begin{array}{c}1.5 \mathrm{~m} \\
\text { above } \\
\text { ground }\end{array}$ & $\begin{array}{l}0.8 \mathrm{~m} \\
\text { above } \\
\text { ground }\end{array}$ & $\begin{array}{c}1.5 \mathrm{~m} \\
\text { above } \\
\text { ground }\end{array}$ & $\begin{array}{l}0.8 \mathrm{~m} \\
\text { above } \\
\text { ground }\end{array}$ & $\begin{array}{l}1.5 \mathrm{~m} \\
\text { above } \\
\text { ground }\end{array}$ & $\begin{array}{l}0.8 \mathrm{~m} \\
\text { above } \\
\text { ground }\end{array}$ & $\begin{array}{l}1.5 \mathrm{~m} \\
\text { above } \\
\text { ground }\end{array}$ \\
\hline & & \multicolumn{2}{|c|}{$\begin{array}{c}\text { Beginning of apple } \\
\text { maturity }\end{array}$} & \multicolumn{2}{|c|}{ Harvest time } & \multicolumn{2}{|c|}{$\begin{array}{c}\text { Beginning of apple } \\
\text { maturity }\end{array}$} & \multicolumn{2}{|c|}{ Harvest time } \\
\hline \multirow[t]{3}{*}{$\mathrm{P} 22$} & $3 \times 1$ & 0.096 & 0.097 & -0.003 & $-0.004 * *$ & 35.00 & 30.05 & 38.34 & 30.61 \\
\hline & $3 \times 0.75$ & 0.094 & 0.108 & $0.046^{* *}$ & 0.036 & 39.88 & 29.65 & 38.67 & 31.10 \\
\hline & $3 \times 0.5$ & 0.111 & 0.101 & $0.054 * *$ & 0.048 & 33.34 & 24.41 & 31.58 & 26.73 \\
\hline \multirow[t]{3}{*}{$\mathrm{P} 60$} & $3 \times 1$ & $0.152 * *$ & $0.179 * *$ & $0.040 * *$ & $0.062 * *$ & 42.15 & 33.57 & 42.88 & 24.40 \\
\hline & $3 \times 0.75$ & $0.160 * *$ & 0.115 & $0.054 * *$ & $0.054 * *$ & 39.84 & 31.82 & $50.92 * *$ & 37.63 \\
\hline & $3 \times 0.5$ & 0.127 & $0.150^{* *}$ & $0.060^{* *}$ & $0.062 * *$ & 40.78 & 25.05 & 39.38 & 37.48 \\
\hline \multicolumn{2}{|c|}{$\mathrm{LSD}_{0.5 \mathrm{AB}}$} & 0.026 & 0.032 & 0.021 & 0.025 & 8.911 & 5.481 & 9.813 & 7.030 \\
\hline \multicolumn{2}{|c|}{$\mathrm{LSD}_{0.1 \mathrm{AB}}$} & 0.035 & 0.043 & 0.028 & 0.033 & 11.83 & 7.277 & 13.028 & 9.334 \\
\hline \multicolumn{10}{|c|}{ F actual } \\
\hline \multicolumn{2}{|c|}{ Factor A (rootstock) } & \multicolumn{2}{|c|}{$* *$} & \multicolumn{2}{|c|}{$* *$} & \multicolumn{2}{|c|}{$*$} & \multicolumn{2}{|c|}{$* *$} \\
\hline \multicolumn{2}{|c|}{ Factor B (Distance) } & \multicolumn{2}{|c|}{ ns } & \multicolumn{2}{|c|}{$* *$} & \multicolumn{2}{|c|}{$*$} & \multicolumn{2}{|c|}{$* *$} \\
\hline \multicolumn{2}{|c|}{$\begin{array}{c}\text { Factor } \mathrm{C} \text { (Measuring } \\
\text { height) }\end{array}$} & \multicolumn{2}{|c|}{ ns } & \multicolumn{2}{|c|}{ ns } & \multicolumn{2}{|c|}{$* *$} & \multicolumn{2}{|c|}{$* *$} \\
\hline \multicolumn{2}{|c|}{ Interaction $\mathrm{AB}$} & \multicolumn{2}{|c|}{$*$} & \multicolumn{2}{|c|}{$* *$} & \multicolumn{2}{|c|}{ ns } & \multicolumn{2}{|c|}{$*$} \\
\hline Interaction & & & & & & & & & \\
\hline Interaction & & & & & & & & & \\
\hline Interaction & $\mathrm{BC}$ & & & & & & & & \\
\hline
\end{tabular}

LSD - Fisher's protected least: ${ }^{*} \mathrm{P}<0.05 ; * * \mathrm{P}<0.01$ shows significant differences, ns - no significant differences. 
Table 2

The effect of rootstock, the distance between trees and seasonality on Specific leaf area and dry and fresh weight ratio in 'Auksis' apple tree

\begin{tabular}{|c|c|c|c|c|c|}
\hline \multirow{2}{*}{ Rootstock } & \multirow{2}{*}{ Distance } & \multicolumn{2}{|c|}{ Specific leaf area, $\mathrm{cm}^{2} \mathrm{~g}^{-1}$} & \multicolumn{2}{|c|}{ Dry/Fresh weight ratio, g } \\
\hline & & $\begin{array}{l}\text { Beginning of apple } \\
\text { maturity }\end{array}$ & Harvest time & $\begin{array}{l}\text { Beginning of apple } \\
\text { maturity }\end{array}$ & Harvest time \\
\hline \multirow[t]{3}{*}{$\mathrm{P} 22$} & $3 \times 1$ & 60.01 & 63.05 & 36.32 & 36.36 \\
\hline & $3 \times 0.75$ & 62.70 & 67.45 & 36.64 & 34.80 \\
\hline & $3 \times 0.5$ & 69.34 & $93.21 *$ & 35.37 & 33.92 \\
\hline \multirow[t]{3}{*}{$\mathrm{P} 60$} & $3 \times 1$ & $121.08^{* *}$ & $101.58 * *$ & 38.09 & $38.68 *$ \\
\hline & $3 \times 0.75$ & $121.71 * *$ & $128.32 * *$ & 38.92 & $38.53 *$ \\
\hline & $3 \times 0.5$ & $134.78 * *$ & $128.33 * *$ & 37.75 & 36.39 \\
\hline \multicolumn{2}{|c|}{$\mathrm{LSD}_{0.5 \mathrm{AB}}$} & 36.965 & 23.277 & 2.39 & 2.01 \\
\hline \multicolumn{2}{|c|}{$\mathrm{LSD}_{0.1 \mathrm{AB}}$} & 52.579 & 33.109 & 3.40 & 2.85 \\
\hline \multicolumn{6}{|c|}{$\mathrm{F}$ actual } \\
\hline \multicolumn{2}{|c|}{ Factor A (Rootstock) } & \multicolumn{2}{|l|}{$* *$} & \multicolumn{2}{|c|}{$* *$} \\
\hline \multicolumn{2}{|c|}{ Factor B (Distance) } & \multicolumn{2}{|l|}{ ns } & \multicolumn{2}{|c|}{$* *$} \\
\hline \multicolumn{2}{|c|}{ Factor C (Season) } & \multicolumn{2}{|l|}{$*$} & \multicolumn{2}{|c|}{ ns } \\
\hline \multicolumn{2}{|c|}{ Interaction $\mathrm{AB}$} & \multicolumn{2}{|l|}{ ns } & \multicolumn{2}{|c|}{ ns } \\
\hline \multicolumn{2}{|c|}{ Interaction $\mathrm{AC}$} & \multicolumn{2}{|l|}{ ns } & \multicolumn{2}{|c|}{ ns } \\
\hline \multicolumn{2}{|c|}{ Interaction $\mathrm{BC}$} & \multicolumn{2}{|l|}{ ns } & \multicolumn{2}{|c|}{ ns } \\
\hline \multicolumn{2}{|c|}{ Interaction $\mathrm{ABC}$} & \multicolumn{2}{|l|}{ ns } & \multicolumn{2}{|c|}{ ns } \\
\hline
\end{tabular}

LSD - Fisher's protected least: ${ }^{*} \mathrm{P}<0.05 ; * * \mathrm{P}<0.01$ shows significant differences, ns - no significant differences.

\section{Results and Discussion}

The impact of light penetration into crown and the effect of rootstocks and distance between trees on photosynthetic behaviour were analyzed. Thus, the NBI and PRI were measured at two heights inside and outside the canopy to assess how these indices change in different lighting conditions. According to the obtained results, the NBI inside the canopy was significantly higher for all treatments compared to fully lightened leaves outside the canopy (Table 1). This data corresponds to the findings by Cronin \& Lodge (2003), as they found that low light availability increased the nitrogen content of leaf tissue by $53 \%$. It was found that NBI increased by about $10 \%$ in apple tree leaves grafted on P60 rootstock compared with the rootstock $\mathrm{P} 22$. According to the results, the planting distance had the most significant impact on the NBI. Increasing the density between trees lead to the decrease of NBI inside and outside the canopy. Twice lower density between the trees resulted in NBI decreased by about $15 \%$. A significant impact on NBI was also found in apple tree cultivar 'Ligol' (Samuolienè et al., 2016).
PRI was about 1.5 times bigger in the leaves of apple tree grafted on P60 rootstock compared with the rootstock P22 in July compared to the harvesting time. $\mathrm{P} 22$ rootstock and $3 \times 1 \mathrm{~m}$ planting distance between trees resulted in the decrease of PRI. Weng et al. (2006) say that PRI can serve as an indicator of the seasonal variation of potential PSII efficiency. In our research, PRI from middle of July till the end of August decreased by a half and more.

Both the distance between the trees and rootstock significantly affected the specific leaf area. The specific leaf area of trees with rootstock grafted on P60 was two times larger compared to the trees grafted on P22 rootstock in all treatments (Table 2). Decreasing the distance between apple trees lead to an increased specific leaf area, but dry and fresh weight ratio (DW/ FW) decreased. On the other hand, DW/FW was significantly affected by the rootstock and the distance between trees, but seasonality had no significant effect. DW/FW of trees with rootstock grafted on P60 had increased by about $6 \%$ compared with rootstock $\mathrm{P} 22$. Meanwhile, there were no significant differences 
between the interactions of factors. Thus, the increase of specific leaf area was caused by dry mass decrease, which was effected by lower light penetration into canopy. Similar results have been obtained by other authors, who have stated that when increasing the density of fruit trees, the dry mass decreases (at the same time DW/FW decrease has been observed), but it results in the increase of SLA (Sims et al., 1994; Poorter \& Nagel, 2000). According to Evans and Poorter (2001), an increase in SLA lead to a decrease of NBI. Moreover, lower light penetration decreases the dry mass and NBI (Cronin et al., 2003). The same tendency was obtained in our research (Table 2).

\section{Conclusions}

1. Decreasing light penetration into the crown results in the increase in SLA and PRI, and leads to a decrease of DW/ FW and NBI.
2. The rootstock has the greatest influence on the photosynthesis indices compared to the planting density and seasonality. The significantly positive effect of dwarfing rootstock P60 on all tested indices was observed compared to P22 rootstock.

3. The distance between the fruit trees significantly increased the specific leaf area and nitrogen balance index, but no general tendency was identified for changes of dry and fresh weight ratio and photochemical reflectance index.

\section{Acknowledments}

This work was carried out within the framework of the long-term research program 'Horticulture: agrobiological basics and technologies' implemented by the Lithuanian Research Centre for Agriculture and Forestry.

\section{References}

1. Ali, A.M., Darvishzadeh, R., Skidmore, A.K., \& Duren, I. (2017). Specific Leaf Area Estimation from Leaf and Canopy Reflectance through Optimization and Validation of Vegetation Indices. Agricultural and Forest Meteorology 236. Elsevier B.V.: 162-174. DOI: 10.1016/j.agrformet.2017.01.015.

2. Cerovic, Z.G., Guillaume, M., Ghozlen, N.B., \& Latouche, G. (2012). A New Optical Leaf-Clip Meter for Simultaneous Non-Destructive Assessment of Leaf Chlorophyll and Epidermal Flavonoids. Physiologia Plantarum 146 (3). Blackwell Publishing Ltd: 251-260. DOI: 10.1111/j.1399-3054.2012.01639.x.

3. Cheng, Y.B., Middleton, E.M., Zhang, Q., Huemmrich, K.F., Campbell, P.K.E., Corp, L.A., Cook, B.D., Kustas, W.P., \& Daughtry, C.S. (2013). Integrating solar induced fluorescence and the photochemical reflectance index for estimating gross primary production in a cornfield. Remote Sens., 5, 6857-6879.

4. Cronin, G., \& Lodge, D. (2003). Effects of Light and Nutrient Availability on the Growth, Allocation, Carbon/nitrogen Balance, Phenolic Chemistry, and Resistance to Herbivory of Two Freshwater Macrophytes. Oecologia 137 (1): 32-41. DOI: 10.1007/s00442-003-1315-3.

5. Evans, J.R., \& Poorter, H. (2001). Photosynthetic Acclimation of Plants to Growth Irradiance: The Relative Importance of Specific Leaf Area and Nitrogen Partitioning in Maximizing Carbon Gain. Plant, Cell and Environment 24 (8): 755-767. DOI: 10.1046/j.1365-3040.2001.00724.x.

6. Gamon, J.A., \& Surfus, J.S. (1999). Assessing Leaf Pigment Content and Activity with a Reflectometer. New Phytologist 143 (1): 105-117. DOI: 10.1046/j.1469-8137.1999.00424.x.

7. Hüner, P.A., Dahal, K., Bode, R., Kurepin, L.V., \& Ivanov, A.G. (2016). Photosynthetic Acclimation, Vernalization, Crop Productivity and 'the Grand Design of Photosynthesis. Journal of Plant Physiology Volume 203, 20 September 2016, pp. 29-43. DOI: 10.1016/j.jplph.2016.04.006.

8. Hmimina, G., Dufrêne, E., \& Soudani, K. (2014). Relationship between photochemical reflectance index and leaf ecophysiological and biochemical parameters under two different water statuses: towards a rapid and efficient correction method using real-time measurements. Plant, Cell and Environment (2014) 37 , 473-487. Journal of Plant Physiology 203. Elsevier GmbH.: 29-43. DOI: 10.1016/j.jplph.2016.04.006.

9. Long, S.P., Zhu, X.G., Naidu, S.L., \& Ort, D.R. (2006). Can Improvement in Photosynthesis Increase Crop Yields? Plant, Cell and Environment 29 (3): 315-330. DOI: 10.1111/j.1365-3040.2005.01493.x.

10. Overbeck, V., Schmitz, M., Tartachnyk, I., \& Blanke, M. (2018). Identification of Light Availability in Different Sweet Cherry Orchards under Cover by Using Non-Destructive Measurements with a Dualex ${ }^{\mathrm{TM}}$. European Journal of Agronomy 93 (November 2017). Elsevier: 50-56. DOI: 10.1016/j.eja.2017.11.006.

11. Poorter, H., \& Nagel, O.W. (2000). The role of biomass allocation in the growth response of plants to different levels of light, CO2, nutrients and water: a quantitative review. Australian Journal of Plant Physiology 27, 595-607. DOI: 10.1071/PP99173_CO.

12. Sala, F., Arsene, G.G., Iordănescu, O., \& Boldea, M. (2015). Leaf Area Constant Model in Optimizing Foliar Area Measurement in Plants: A Case Study in Apple Tree. Scientia Horticulturae 193: $218-224$. DOI: $10.1016 /$ j.scienta.2015.07.008. 
13. Samuolienė, G., Viškelienè, A., Sirtautas, R., \& Kviklys, D. (2016). Relationships between Apple Tree Rootstock, Crop-Load, Plant Nutritional Status and Yield. Scientia Horticulturae 211: 167-173. DOI: 10.1016/j.scienta.2016.08.027.

14. Sims, D.A., Gebauer, R.L.E., \& Pearcy, R.W. (1994). Scaling sun and shade photosynthetic acclimation of Alocasia macrorrhiza to whole-plant performance - II. Simulation of carbon balance and growth at different photon flux densities. Plant, Cell and Environment 17, 889-900. DOI: 10.1111/j.1365-3040.1994. tb00318.x.

15. Stagakis, S., Markos, N., Sykioti, O., \& Kyparissis, A. (2014). Tracking seasonal changes of leaf and canopy light use efficiency in a Phlomis fruticosa Mediterranean ecosystem using field measurements and multi-angular satellite hyperspectral imagery. ISPRS Journal of Photogrammetry and Remote Sensing. 97, 138-151. DOI: 10.1016/j.isprsjprs.2014.08.012.

16. Weng, J.H., Jhaung, L.H., Lin, R.J., \& Chen, H.Y. (2010). Relationship between photochemical efficiency of photosystem II and the photochemical reflectance index of mango tree: merging data from different illuminations, seasons and leaf colors. Tree Physiologic. Apr; 30(4): 469-478. DOI: 0.1093/treephys/ tpq007.

17. Weng, J.H., Chen, Y.N., \& Liao, T.S. (2006). Relationships between chlorophyll fluorescence parameters and photochemical reflectance index of tree species adapted to different temperature regimes. Functional Plant Biology 33, 241-246. DOI: 10.1071/FP05156.

18. Yao, H., Zhang, Y., Yi, X., Zhang, X., \& Zhang, W. (2016). Cotton Responds to Different Plant Population Densities by Adjusting Specific Leaf Area to Optimize Canopy Photosynthetic Use Efficiency of Light and Nitrogen. Field Crops Research 188. Elsevier B.V.: 10-16. DOI: 10.1016/j.fcr.2016.01.012. 